\title{
MENAKAR KEADILAN HUKUM WARIS ISLAM MELALUI PENDEKATAN TEKS DAN KONTEKS AL-NUSHÛSH
}

\author{
Muhammad Amin Suma \\ Fakultas Syariah dan Hukum UIN Jakarta \\ Jl. Ir. H. Juanda 95, Ciputat, Jakarta \\ E-mail: aminsuma@yahoo.com
}

\begin{abstract}
Measuring the Justice of Islamic Inheritance Law by Drawing upon the Text and Context of al-Nushûsh. Accusations against the Islamic inheritance distribution system are surfacing again. Several groups are finding fault with the 2:1 distribution for Islamic inheritors. They suggest this distribution method be converted into 1:1, like it is in the Western system of inheritance and like it is to some extent in Adat inheritance law. This study points out that theoretically Islamic inheritance law looks very clear, comprehensive and fair, from whatever angle you look at it. This takes into account, in a balanced way, the distributions that use the 2:1 approach for joint male and female heirs. The key to understanding this is inheritance has to be treated entirely as a sub-system of the family law system, and even has to be understood as an integral part of the whole Islamic legal system, which is sound and comprehensive.
\end{abstract}

Keywords: justice, inheritance law, textual, al-nushûsh

\begin{abstract}
Abstrak: Menakar Keadilan Hukum Waris Islam Melalui Pendekatan Teks dan Konteks al-Nushûsh. Gugatan mengenai sistem pembagian kewarisan Islam kembali muncul ke permukaan. Beberapa kalangan mempermasalahkan perimbangan waris Islam 2:1. Mereka menawarkan metode perimbangan ini menjadi 1:1, sebagaimana pada sistem hukum kewarisan Barat dan sebagian hukum kewarisan Adat. Studi ini menunjukkan bahwa dari sisi mana pun hukum kewarisan Islam secara teoretik tampak sangat jelas, lengkap, dan adil. Termasuk dalam konteks perimbangan pembagiannya yang menggunakan pendekatan 2:1 untuk ahli waris laki-laki dan ahli waris perempuan. Kunci untuk memahaminya harus menempatkan posisi kewarisan sebagai sub sistem dari sistem hukum keluarga secara keseluruhan bahkan harus dipahami sebagai bagian integral dari keseluruhan sistem hukum Islam yang bersifat utuh dan menyeluruh.
\end{abstract}

Kata Kunci: keadilan, hukum kewarisan, tekstual, al-nushîsh

\section{Pendahuluan}

Setiap umat Islam, kapan dan di manapun, meyakini bahwa sumber utama dan pertama hukum Islam adalah Alquran. Baru kemudian diiringi dengan Hadis sebagai sumber penting kedua, dan lalu disertai dengan serangkaian hukum buatan manusia secara kolektif, terutama peraturan perundang-undangan (legislasi), di samping yang lain-lain. Sebagai sumber hukum, Alquran menjuluki hukum Islam sebagai hukum yang sempurna, dan Allah juga menyatakan kerelaan-Nya untuk menjadikan hukum Islam sebagai hukum bagi semua dan setiap umat manusia. ${ }^{1}$

Sungguhpun demikian, kesempurnaan sistem hukum Islam tidak serta-merta meniadakan sama sekali riak-riak pertanyaan, protes, atau bahkan "hujatan" oleh atau dari sebagian orang terhadap Islam. Termasuk

Naskah diterima: 23 Januari 2012, direvisi: 16 Mei 2012, disetujui untuk terbit: 30 Mei 2012.

${ }^{1}$ Perhatikan Alquran, antara lain surah al-Mầidah [5]: 3. dari kalangan insan-insan yang mengaku diri Muslim, bahkan tidak jarang dari kalangan yang sangat terpelajar sekalipun dengan gelar kesarjanaan yang bervariasi, mulai dari S-1, S-2, hingga S-3. Di antara sub sistem hukum syariat yang sampai kini tetap digugat dan bahkan terkadang dihujat sebagian orang ialah terkait dengan "kekurangadilan" hukum kewarisan. Terutama terkait dengan perimbangan pembagian 2:1, dengan maksud dua bagian untuk ahli waris laki-laki dan satu bagian untuk ahli waris perempuan. Khususnya antara anak laki-laki dan anak perempuan, di samping antara suami dan istri.

Dalam merespons gugatan "kekurangadilan" hukum kewarisan Islam - terkait metode perimbangan 2:1—ini tentu saja disertai dengan sejumlah argumentasi, mulai dari yang paling sederhana dengan berpikir sosiologisempiris dan pragmatis, sampai kepada pendalilan dan pendalihan yang didasarkan atas konsep dan sistem berpikir yang boleh jadi dianggap paling filosofis, 
metodologis, dan argumentatif. Sikap pro dan kontra para ilmuwan dalam menyikapi rumus pembagian waris Islam-yang menggunakan metode perimbangan 2:1 - ini masih terus dan akan tetap menjadi wacana sampai di waktu-waktu yang akan datang.

\section{Ayat-ayat Kewarisan}

Terdapat perbedaan persepsi di kalangan para ahli tentang jumlah ayat mawârîts. Ada yang menyebutkan sekitar lima sampai enam ayat, dan ada juga yang menyebutkan lebih banyak lagi dari itu. Pangkal perbedaan para ahli tentang ayat-ayat mawârîts, terutama terletak pada ketidaksamaan pendirian mereka dalam menyikapi ayat-ayat yang pada satu sisi tidak tegastegas berisikan ihwal penentuan ahli waris maupun bagian masing-masing, sementara pada sisi yang lain, ayat-ayat itu tetap memiliki keterkaitan (munâsabah) yang langsung dengan ayat-ayat induk mawârîts itu sendiri. Baik karena tata letak (penempatan) ayatnya yang berdampingan dengan ayat-ayat utama mawârits, maupun mengingat isinya yang sangat berhubungan dengan spirit ayat-ayat mawârîts. Di antara contohnya adalah ayat 8 dan 9 surah al-Nisầ [4] yang isinya antara lain mengingatkan manusia dari kemungkinan meninggalkan keturunan yang lemah secara ekonomi; dan demikan pula dengan ayat 13 dan 14 surah yang sama, yang berisikan janji baik dan ancaman buruk (al-wa'd wa al-wa'îd) bagi siapa saja yang menaati dan mengabaikan hukum kewarisan.

Dengan mengabaikan sementara perbedaan dan perdebatan pendapat tentang itu, penulis hendak mencoba memilahkan ayat-ayat mawârits ke dalam tiga kelompok besar yakni kelompok ayat induk/inti, kelompok ayat pendukung, dan kelompok ayat terkait.

Pertama, kelompok ayat induk/inti (al-Nisâ’ [4]: 7, 11, 12 dan 176). Ayat-ayat induk mawârîts di atas secara jelas, gamblang, tegas, dan lugas menentukan bahwa semua dan setiap ahli waris, oleh ayat 7 surah al-Nisâ' dijamin mendapatkan hak bagian warisan tanpa membeda-bedakan jenis kelamin (laki-laki atau perempuan), usia, dan/atau lainnya. Ayat 11 dan 12 surah al-Nisầ, lalu menetapkan dan memastikan siapasiapa saja yang berhak menjadi ahli waris, berapa bagian masing-masing, dan kapan tirkahsi mayit bisa dibagikan. Dari beberapa ayat di atas, para pakar menyebutkan 15 orang ahli waris berjenis kelamin laki-laki dan 10 orang ahli waris berjenis kelamin perempuan.

Kedua, kelompok ayat pendukung (al-Nisâ [4]: 22, 23 dan 24). Selain ayat-ayat induk faraid sebagaimana baru saja dikutipkan, ada ayat-ayat lain yang secara langsung memiliki hubungan dengan ayat-ayat waris induk di atas, baik dari sisi peletakkannya maupun dari sisi informasi dan pemaknaan yang terkandung di dalamnya, meskipun tidak berisikan ahli waris dan/atau bagian masing-masing ahli waris. Beberapa ayat lain yang secara langsung memiliki korelasi (munâsabah) dengan atau bahkan memperkuat posisi ayat-ayat kewarisan dan apalagi dengan kehartabendaan pada umumnya, terutama al-Nisầ [4]: 9-10 dan al-Nisầ [4]: 13-14).

Ayat-ayat pendukung mawârîts di atas, berisikan filsafat dan/atau hikmah hukum yang sungguh luar biasa di luar jangkauan kemampuan daya nalar, daya rasa, dan apalagi daya jangkau inderawi manusia yang sangat terbatas dan subyektif. Ayat 9 surah al-Nisầ [4], yang mengingatkan semua keluarga khususnya ibu dan terutama ayah yang diingatkan betul jangan sampai meninggalkan anak-anak dan keturunan dalam kondisi yang lemah (tertinggal), baik secara fisik-material maupun mental-spiritual, misalnya kekurangan gizi, apalagi mengidap gizi buruk dan idiot.

Adanya ayat yang mengingatkan jangan sampai meninggalkan anak keturunan yang lemah materi, ini sangat mungkin yang dimaksudkan adalah juga rahasia pembagian harta warisan yang menganut perimbangan 2:1 bagi laki-laki dan perempuan. Bagi anak laki-laki telah dipersiapkan sama dengan dua bagian anak perempuan-mengingat anak laki-laki yang masih kecil—itu sudah "dibayang-bayangi" beban keluarga kelak begitu dia dewasa yang ditandai dengan pintu gerbang perkawinan. Sementara anak-anak perempuan, sama sekali tidak digelayuti oleh beban kewajiban untuk menafkahi keluarga, yang ada malah sebaliknya, ia/mereka (anak-anak perempuan) boleh jadi sudah menggadang-gadang akan mendapatkan pemberian mahar dan nafkah dari para suaminya. Di sinilah terletak rahasia ayat yang menyatakan, "Kalian (manusia) sama sekali tidak mengetahui betul, siapa di antara mereka yang akan lebih banyak/besar manfaatnya dengan ketentuan pembagian harta kewarisan yang seperti itu."

Beralih kepada ayat 10 surah al-Nisầ [4], yang mengancam para pihak yang menyelewengkan hak-hak kewarisan yatim, memberikan isyarat betapa dahsyat ancaman hukuman bagi pemakan harta anak-anak yatim dengan cara yang batil itu. Permasalahannya kini, apakah menyamaratakan bagian anak laki-laki dengan anak perempuan itu tidak tergolong ke dalam penyelewengan hak harta anak yatim, dalam kasus ini pengambilan bagian anak laki-laki karena pemberian bagian yang tidak penuh itu dipastikan tidak termasuk ke dalam kategori memakan harta anak yatim dimaksud? Pada saat yang bersamaan, pemberian bagian waris yang lebih kepada anak perempuan, apakah juga tidak dapat dikategorikan ke dalam pemakan riba lantaran 
secara sepihak mengambil harta anak laki-laki tanpa sepengetahuan atau sepersetujuan dari anak laki-laki itu sendiri? Boleh jadi ini dianggap penafsiran yang terlalu jauh dan tidak logis. Tetapi, memaksakan pembagian harta waris anak laki-laki dan anak perempuanterutama yang berstatus yatim-juga merupakan hal yang tidak kurang bodohnya. Pemikiran yang demikian, tentu sama-sama tidak logis dan sama-sama subyektif. Hanya saja, satu hal yang perlu diingatkan di sini ialah bahwa ukuran logis atau tidaknya diukur dari standar pemikiran, atau tepatnya perasaan manusia sematamata, bukan dari segi substansi hukum waris Islam itu sendiri.

\section{Ayat-ayat Terkait}

Sesungguhnya memang ada sedikit kesulitan untuk membedakan antara ayat-ayat pendukung dan ayatayat terkait di sini, mengingat sifatnya yang saling mendukung dan menguatkan. Namun demikian, yang penulis maksudkan dengan ayat terkait adalah ayatayat yang dari sudut pandang substansi kepatuhan terhadap ayat-ayat kewarisan itu memiliki hubungan yang sangat jelas. Sedangkan yang dimaksud dengan ayat-ayat pendukung seperti halnya ayat 9 dan 10 surah al-Nisầ, serta ayat 13 dan 14 yang dikutipkan di atas, terutama dengan memperhatikan tata letaknya yang berada dalam bingkai ayat-ayat mawârîts. Ayatayat terkait dengan ihwal kewarisan, apalagi dengan kehartabendaan rumah tangga, ini sangat banyak sekali jumlahnya. Sebagian dari padanya adalah sebagai berikut: al-Baqarah [2]: 228, al-Nisầ [4]: 19, al-Nisầ [4]: 32 - 34, al-Ahzzâb [33]: 4, al-Baqarah [2]: 138139, al-Nisầ [4]: 65, a-Mầidah [5]: 1, al-Ahzâb [33]: 36, al-Mầidah [5]: 43-44, al-Mầidah [5]: 47-48, dan al-Mầidah (5): 49-50.

Ayat-ayat di atas, secara sendiri-sendiri-dan terlebih secara kolektif-pada satu sisi mengingatkan umat Islam supaya konsisten (istikamah) dalam menaati atau mematuhi hukum-hukum Allah tanpa reserve. Sementara pada sisi yang lain, ayat-ayat di atas juga mempertanyakan loyalitas dan menegur kesangsian umat Islam terhadap keberadaan hukum-hukum Allah dan/atau hukum-hukum nabi-Nya, baik terkait dengan hukum kewarisan pada khususnya maupun terhubung dengan bidang-bidang hukum yang lain pada umumnya. Ayat-ayat di atas, ada yang bersifat umum terkait dengan semua sistem hukum Islam secara keseluruhan, dan ada pula yang secara spesifik terkait dengan ihwal hukum kewarisan.

\section{Sistem Hukum Kewarisan Pra Islam}

Umumnya, riwayat menyebutkan bahwa kalangan jahiliah pra Islam, kapan dan di manapun, tidak hanya di wilayah jazirah Arab sebagaimana yang umum disebut oleh para penentang hukum Islam, khususnya hukum kewarisan, sama sekali tidak memberikan warisan kepada kaum perempuan dan anak-anak. Mereka, kaum jahiliah pra Islam di seantero jagat raya ini, hanya memberikan warisan kepada keturunan laki-laki dewasa, itupun dengan ukuran kedewasan yang semata-mata fisically. Mereka memiliki adagium hukum yang menyatakan bahwa "siapapun tidak berhak memperoleh warisan, selain yang mampu memanah (berperang), menghalau musuh, dan memperoleh rampasan perang."

Hukum warisAdatjahiliah pra Islam ini menyebutkan tiga penyebab utama saling mewarisi (asbâb al-irts). Pertama, karena nasab, yang diartikan dengan anak laki-laki dewasa yang sudah teruji mampu memanggul senjata, dan sama sekali tidak melibatkan keturunan "yang lemah" dalam hal ini kaum perempuan dewasa sekalipun, dan demikian pula tidak menyertakan anakanak yang laki-laki sekalipun.

Kedua, anakangkat (al-tabannî), yakni pengangkatan anak (laki-laki) orang lain oleh seseorang untuk kemudian secara de facto maupun de jure diakui sebagai anak sendiri laiknya seorang anak kandung yang juga mendapatkan hak waris di samping hak-hak lainnya.

Ketiga, perjanjian dan/atau sumpah setia (al-'ahd wa al-hilf), dalam mana seseorang berjanji seraya bersumpah dengan mengatakan kepada yang lain bahwa, "darahku adalah juga darahmu, dan kehancuranku adalah juga berarti kehancuranmu (دمى دمك وهدمى هدمك), dan karenanya maka kamu berhak mewarisi aku dan aku pun berhak mewarisi kamu. Ketika usai melakukan janji/sumpah setia itu salah satunya meninggal dunia, maka orang lain yang masih hidup, secara otomatis menjadi ahli warisnya. ${ }^{2}$

Begitu agama Islam datang, dari tiga faktor penyebab utama kewarisan di atas hanya dua saja yang diakui dalam arti dibenarkan dan diabadikan, yaitu faktor al-nasab dan al-bilf wa al-'ahd (janji-sumpah setia). Sedangkan faktor kedua, yaitu pengangkatan anak (altabannî), ditolak dan dihapuskan oleh Islam. ${ }^{3}$ Hanya saja, ketika itu hukum Islam masih membenarkan toleransi terhadap dua faktor penyebab kewarisan lainnya, yakni kewarisan yang didasarkan atas persaudaraan karena hijrah (migrasi) dan kewarisan yang didasarkan atas persaudaraan (al-mu'akhah) bentukan semacam saudara angkat—karena Rasulullah Saw. sendiri sesampai di Madinah, memang melakukan gerakan penyaudaraan silang antara "pendatang" dari

\footnotetext{
${ }^{2}$ Ahmad Mushthafâ al-Marâghî, Tafsîr al-Marâghî, (BayrûtLubnân: Dâr al-Fikr, t.th.), Jilid II, h. 194-195.

${ }^{3}$ Perhatikan dan renungkan Alquran surah al-Ahzzâb [33]: 4.
} 
luar Madinah dengan yang berasal-usul dari Madinah. ${ }^{4}$ Tetapi, beberapa waktu kemudian, kewarisan yang didasarkan atas migrasi maupun persaudaraan bentukan itu kemudian ditiadakan dan karenanya maka penyebab terjadinya kewarisan yang ditetapkan dan diabadikan oleh hukum Islam adalah tiga hal, yakni: al-nasab, alnikâhlal-zawjiyyah, dan al-walâ' (pemerdekaan budak).

Terkait kewarisan adat jahiliah pra Islam, ada lagi yang lebih tidak beretika—bukan sekadar tidak adilyakni kebolehan anak laki-laki tertua atau keluarganya mewarisi istri-istri (janda-janda) yang ditinggal mati ayahnya, untuk dia kawini sendiri atau dikawinkannya dengan keluarga atau orang lain dengan menjadikannya sebagai sarana "bisnis" melalui pembayaran mahar terselubung sebagaimana tersirat dan tersurat dalam surah al-Nisầ [4]: 19. Betapa buruknya hukum adat jahiliah pra Islam yang menyamakan kaum perempuan dengan barang-barang material dalam arti bisa diwarisi dan jika ada kesempatan malah diperdagangkan. Lebih bejat lagi ketika perempuan yang boleh diwarisi itu adalah notabene mantan istri ayahnya yang sampai kapan pun haram untuk dinikahi sebagaimana tersurat dalam surah al-Nisầ (4): 22-23.

Hukum Islam menghapus hukum kewarisan adat jahiliah di atas yang hanya berpihak kepada kaum laki-laki dewasa dengan menutup rapat keterbukaan pintu hak kewarisan bagi kaum perempuan dan anakanak. Hukum adat macam ini sesungguhnya bukan hanya milik dunia Arab zaman silam, melainkan juga merupakan hukum adat pelbagai belahan "dunia" termasuk Indonesia, sekurang-kurangnya di daerahdaerah tertentu. Perhatikan, misalnya, adat masyarakat Lampung yang hanya memberikan warisan kepada putera tertua. Demikian pula dengan adat masyarakat Bali dan beberapa daerah lainnya yang tidak meratakan harta kewarisan kepada semua ahli waris. Demikian pula dengan hukum adat sebagian masyarakat Nusa Tenggara Barat yang tidak memasukkan benda-benda bergerak (al-manqûlah) ke dalam harta peninggalan si mayit (tirkah).

Sistem kewarisan yang menyerahkan semua harta warisan kepada anak laki-laki tertua itu, baik dalam adat Bali maupun adat Lampung, diimbangi dengan tanggung jawab moral harus menghidupi keluarga, khususnya saudara-saudara perempuannya atau yang masih kecil. Namun, siapakah yang bisa menjamin bahwa dia akan berlaku baik dan seadil mungkin terhadap keluarganya itu. Padahal, seperti diketahui pula kasusnya bahwa banyak saudara menjadi retak lantaran kecemburuan atau berebut harta, sebagaimana

${ }^{4}$ Aḥmad Mushthafâ al-Marâghî, Tafsìr al-Marâghî, Jilid II, h. 194195. diingatkan Alquran bahwa keluarga dan harta benda itu tidak lebih dan tidak kurang mengandung sisi ujian (fitnah, dalam bahasa Alquran).

Guna memperbarui hukum Adat jahiliah pra Islam di atas, kapan saja dan di mana saja, maka Alquran menurunkan beberapa ayat kewarisan. Salah satunya adalah ayat 7 surah al-Nisầ [4], yang dalam banyak riwayat disebutkan bahwa ayat 7 surah al-Nisầ [4], ini untuk kali pertama diturunkan terkait dengan kasus Aws ibn Tsâbit al-Anshârî, yang wafat dengan meninggalkan ahli waris sebagai berikut: satu orang istri [Ummu Kahah], tiga orang anak perempuan, dan dua orang adik laki-laki [Suwayd dan Arjafah/'Arfajah] alias paman ketiga anak perempuan Aws. Sesuai dengan hukum Adat kewarisan Arab jahiliah, maka yang berhak mewarisi harta peninggalan (tirkah) al-Anshârî adalah hanya Suwayd dan Arjafah. Sementara empat ahli waris lainnya, masing-masing Ummu Kahah (istri Aws) dan tiga orang anak perempuannya, tidak mendapatkan bagian apa-apa.

Menyaksikan kenyataan hukum kewarisan adat jahiliah pra Islam-yang tidak merata bahkan diskriminatif dan zalim_itulah maka Ummu Kahah (istri mendiang Aws) memperjuangkan hak-hak keperempuanannya dengan melakukan advokasi kepada Rasulullah Saw. seraya mengisahkan kasus kewarisan yang dialami, baik oleh dirinya sendiri dan terutama oleh ketiga anak perempuannya yang masih gadis atau bahkan masih kecil (belum bersuami) yang sama sekali tidak memperoleh bagian apapun. Atas pengaduan Ummu Kahah itu pula, maka Rasulullah Saw. memanggil Suwayd dan Arjafah guna menanyakan hal itu. Keduanya memberikan jawaban bahwa dalam hukum Adat yang mereka kenal, yang berhak menerima warisan itu hanyalah ahli waris laki-laki yang sudah dewasa dengan ukuran mampu mencari nafkah dan jika perlu melalui peperangan. Sementara mereka (Ummu Kahah dan ketiga anak perempuan al-Anshârî), yang semuanya perempuan itu, kata Suwayd dan Arjafah, tidak mampu memanggul senjata (berperang). ${ }^{5}$

Atas jawaban Suwayd dan Arjafah itu, lalu Rasulullah pun mempersilakan keduanya supaya kembali (pulang), hingga beliau mendapatkan wahyu, dalam hal ini Alquran ayat 7 surah al-Nisầ [4]) yang telah dikutipkan sebelum ini. Pada intinya, ayat 7 surah al-Nisâ [4], ini menghapuskan (me-nasakh) hukum adat waris jahiliah yang memberikan hak kewarisan hanya kepada ahli waris tertentu, dalam hal ini laki-laki dewasa, dan itupun instrumen pengukurannya lebih didasarkan

5 'Abd al-Azhîm Ma'ânî dan Ahmad al-Ghundûr, A $\underline{h} k \hat{a} m$ min alQur'ân wa al-Sunnah, (Mishr: Dâr al-Ma'ârif, 1387 H/1967 H.), h.

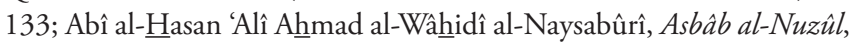
(Bayrût, Lubnân: Dâr al-Fikr, t.th), h. 95-96. 
pada standar fisik-biologis, dalam hal ini kemampuan berperang, bukan karena kedewasaan yang lebih bersifat psikologis. Sebaliknya, ayat ini memberikan jaminan dan perlindungan hukum kepada semua dan setiap ahli waris tanpa membeda-bedakan jenis kelamin (lakilaki dan perempuan) atau umur (usia lanjut maupun kanak-kanak, bahkan janin yang masih berada dalam kandungan ibunya sekalipun), dijamin dan dilindungi hak-hak kewarisannya oleh ayat di atas.

Jaminan dan perlindungan hukum yang dimaksudkan ialah bahwa setiap ahli waris, laki-laki maupun perempuan, Allah jamin dan lindungi untuk mendapatkan bagian harta waris, apakah harta warisan yang ditinggalkan si mayit—dalam kasus turun ayat ini adalah harta peninggalan al-Anshârî—itu jumlah dan nilainya terbilang sedikit ataupun banyak. Yang pasti, semua ahli waris yang ditinggalkan orang tua atau kerabat lainnya, semuanya dijamin penuh mendapatkan hak-hak kewarisan dari harta si mayit.

Ayatinibenar-benarmenyamakandanmenyejajarkan status keahliwarisan anak dan kerabat lainnya, tanpa melihat jenis kelamin maupun usia sebagaimana yang dijadikan standar oleh hukum adat dunia waktu itu, terutama Adat jahiliah bangsa Arab pra Islam. Bahwa oleh sebagian orang atau pihak, jaminan pembagian kewarisan itu dianggap (bukan dirasakan) tidak adil, itu merupakan soal lain yang tidak dijelaskan oleh ayat 7 surah al-Nisâ’ [4], namun secara tersirat diisyaratkan pada ayat lain, yakni surah al-Nisầ [4] ayat 32-34.

Dengan ayat 7 surah al-Nisầ [4], semua dan setiap ahli waris, terutama $d z a w$ al-furûdh, secara hukum dipastikan mendapatkan bagian tertentu yang telah diatur sedemikian rupa oleh Alquran. Ayat 7 surah al-Nisâ' [4] ini, sekali lagi, paling sedikit memberikan jaminan dan perlindungan hak kewarisan bagi setiap ahli waris yang tidak mempermasalahkan lagi jenis kelamin maupun usia kedewasaan. Hanya saja, ayat ini masih bersifat global (mujmal) belum lagi mengatur secara rinci (tafshîlî) bagian ahli waris masing-masing. Pembagian secara rinci ditetapkan beberapa waktu setelah itu, tepatnya melalui rangkaian ayat 11 dan 12 surah yang sama (al-Nisầ [4]).

Terkait dengan penurunan ayat-ayat kewarisan, Alquran melalui surah al-Nisầ [4] ayat 7, mula-mula memastikan dulu jaminan dan perlindungan hukum semua ahli waris demi menentramkan mereka (para ahli waris). Baru pada tahapan berikutnya, Alquran melalui ayat 11 dan 12 surah al-Nisầ [4], menetapkan siapasiapa saja yang berhak menjadi ahli waris, berapa bagian masing-masing, kapan harta kewarisan itu dibagikan, dan bagaimana pula cara penyelesaian beberapa kewajiban si mayit terkait dengan persoalan wasiat dan/ atau utang-piutang (kalau ada). Inilah yang kemudian dikembangkan oleh para mufassir ayat ạhkâm, ahli-ahli Hadis hukum, dan terutama ahli-ahli fikih di samping khususnya ahli-ahli hukum kewarisan Islam, mulai dari teksnya yang bersifat umum dan teoretis, sampai konteksnya yang bersifat spesifik dan praksis. ${ }^{6}$

Di antara hal penting yang bersifat mendasar pada ayat di atas, bahkan juga ayat lain (al-Nisầ [4] : 176), adalah tentang perimbangan bagian kewarisan yang dalam kasus-kasus tertentu, perimbangannya adalah dua berbanding satu (2:1), dalam hal ini antara suami dengan istri, antara anak laki-laki dengan anak perempuan,; dan dalam kasus-kasus tertentu antara ayah dan ibu, antara saudara laki-laki dan saudara perempuan, serta antara cucu laki-laki dan cucu perempaun.

Mencermati redaksi ayat di atas, tampak jelas memang perimbangan 2:1 dengan maksud dua bagian untuk anak laki-laki dan satu bagian untuk anak perempuan dalam penggalan ayat للدكر مثل حظ الأنيين (bagi anak laki-laki, itu sama bagiannya dengan bagian dua orang anak perempuan). Kalimat ini diulang dua kali, yakni dalam ayat 11 dan ayat 176 surah alNisầ [4]. Seperti ditegaskan sebelum ini, pembagian kewarisan yang menggunakan porsi 2:1 inilah yang sering kali dipertanyakan, digugat, atau bahkan tidak jarang dihujat oleh sebagian orang/pihak yang kurang pas dengan pembagian kewarisan ala hukum faraid ini. Termasuk dari kalangan internal orang-orang Islam sendiri. Terutama di era modern sekarang, ketika dunia kerja tidak lagi menjadi monopoli kaum adam (lakilaki), banyak berekses pada pembiayaan kehidupan dan penghidupan rumah tangga (keluarga). "Kongsi" untuk menghidupi keluarga/rumah tangga inilah yang sering dirujuk menjadi salah satu argumentasi untuk menekan supaya para pakar hukum Islam menyamaratakan pembagian kewarisan antara anak laki-laki dan anak perempuan, di samping penyamarataan antara bagian suami dengan bagian istri. ${ }^{7}$

\section{Beberapa Prinsip Hukum Kewarisan Islam}

Ada beberapa kaidah prinsip kewarisan Islam yang dikemukakan oleh pakar-pakar hukum Islam. Di antaranya Mahmûd Syaltût, Syaykh al-Azhar, yang menyebutkan lima dasar pembinaan kewarisan dalam Islam, terutama terkait dengan hak mendapatkan bagian (istihqaq al-irtsi).

Pertama, kewarisan didasarkan atas hubungan

${ }^{6}$ Para pembaca dianjurkan supaya membaca kitab/buku-buku fikih dan atau hukum kewarisan Islam yang sekarang ini demikian dahsyat banyaknya, dan ditulis para pakar dalam berbagai bahasa.

7 Beberapa kasus putusan Mahkamah Agung memang telah ada yang memberikan bagian sama atau sama bagian antara anak laki-laki dengan bagian anak perempuan. 
kekerabatan dan perkawinan ('alaqatay al-qarabah wa-al-zawjiyyah). Kedua, pengabaian gender, dalam pengertian tidak mempersoalkan sifat-sifat kelakilakian atau kebapakan (patrilinial), keperempuanan atau keibuan (matrilinial), maupun usia kanak-kanak atau dewasa. Ketiga, Ahli waris garis ke atas dan ke bawah, yakni al-ushôl dan al-furû, sama sekali tidak ada yang gugur, apalagi digugurkan dari hak untuk mendapatkan warisan dalam keadaan apa dan kondisi bagaimanapun, meskipun dalam keadaan tertentu bisa jadi keberadaannya dapat mengubah atau bahkan mengubah-ubah bagian antara yang satu dengan yang lain.

Keempat, pada dasarnya tidak ada hak kewarisan bagi saudara laki-laki maupun saudara perempuan dengan sebab keberadaan kedua orang tua walaupun mereka menempati tempat ibu dengan hak perolehan $1 / 3$ hingga $1 / 6$ bagian. Kelima, ketika dalam kelompok ahli waris itu berkumpul laki-laki dan perempuan, maka ahli waris laki-laki mengambil kelipatan dari bagian perempuan. ${ }^{8}$

\section{Gugatan dan Pembelaan Terhadap Pembagian Hak Waris 2:1}

Seperti diketahui, pembagian kewarisan Islamyang dalam kasus-kasus tertentu berdasarkan perimbangan 2:1 untuk ahli waris laki-laki dan ahli waris perempuan-kini sering dipertanyakan oleh beberapa orang/pihak. Gugatan semacam ini, sesungguhnya bukanlah hal baru, mengingat sejak masa-masa awal Islam sesungguhnya pernah juga "dipertanyakan" oleh sebagian sahabat Nabi Saw., paling tidak melalui istri Rasulullah Saw.

Diriwayatkan bahwa Ummu Salamah, salah seorang isteri Rasulullah Saw., pernah menyampaikan "kegalauannya" terkait beberapa persoalan hukum Islam. Intinya, dari Mujâhid, ia berkata, Ummu Salamah bertanya kepada nabi Muhammad Saw., "Ya Rasulullah Saw., (mengapa) laki-laki (dibolehkan atau bahkan diperintah) melakukan peperangan, sementara kami yang perempuan, tidak disertakan? (Apa karena itukah) maka kami (kaum perempuan) hanya mendapatkan setengah bagian dalam urusan kewarisan?" Lalu Allah menurunkan surah al-Nisầ [4]: 22 yang pada intinya

8 Sejumlah ulama konteporer, apalagi ulama-ulama zaman klasik, selalu menyertakan prinsip hak mendapatkan kewarisan karena hubungan pemerdekaan budak (al-walâ) di samping kekerabatan dan terutama perkawinan. Dahulu, perbudakan memang diakui keberadaannya secara hukum. Kini perbudakan itu dalam bentuknya yang bagaimanapun, secara yuridis legal-formal sudah tidak lagi diakui keberadaannya. Karenanya, maka mudah dimengerti ketika sebagian pakar hukum Islam, di antaranya Mahmûd Syaltût, tidak lagi mencantumkan al-walâ' sebagai salah satu penyebab ada kewarisan. melarang kaum perempuan cemburu, atau tepatnya iri hati, atas perbedaan bagian warisan antara lakilaki dan perempuan. Riwayat dari 'Ikrimah juga menyebutkan bahwa beberapa orang perempuan sempat mempersoalkan perihal hukum jihad yang tidak melibatkan kaum perempuan, seraya berujar, "Betapa senang kami sekiranya Allah melibatkan kami turut berperang dan karena itu maka kami juga mendapatkan apa (bagian/imbalan) yang diperoleh kaum laki-laki.”

Qatadah dan al-Sudi mengatakan bahwa ketika penggalan ayat للدكر مثل حظَ الأنيين diturunkan, kaum lakilaki berharap benar untuk memperoleh kebaikan yang lebih (berlipat) di akhirat kelak sebagaimana Allah lebihkan bagian laki-laki dalam hal pembagian warisan daripada bagian kaum wanita. Sebaliknya, kaum wanita berharap supaya ancaman hukuman di akhirat kelak atas dosa-dosa yang diperbuatnya di dunia akan diringankan oleh Allah sebagaimana mereka menerima sebagian saja bagian warisnya dari bagian kaum lakilaki. Atas saling gumam kaum laki-laki dan kaum perempuan ini lalu Allah menurunkan ayat 22 surah al-Nisầ [4] di atas ${ }^{9}$ yang meredaksikannya dengan ungkapan, "Dan janganlah kalian (kaum perempuan) berandai-andai untuk menuntut hak yang sama dalam hal pembagian kewarisan".

Orang atau pihak yang mempermasalahkan perimbangan waris Islam 2:1, sangat setuju untuk mengubah metode perimbangan ini menjadi $1: 1$, sebagaimana laiknya sistem hukum kewarisan Barat dan sebagian hukum kewarisan Adat. Maksudnya, seorang anak perempuan harus mendapatkan bagian sama dengan bagian anak laki-laki. Demikian pula halnya dengan bagian istri yang harus sama besar atau sama banyak dengan bagian suami, serta bagian ibu yang juga harus sama banyak dengan bagian ayah. Begitulah seterusnya, termasuk bagian saudara perempuan yang harus sama dengan bagian saudara laki-laki, serta bagian cucu perempuan yang harus juga sama dengan bagian cucu laki-laki.

Para "penggugat" perimbangan pembagian waris 2:1 menjadi 1:1 umumnya berpendapat bahwa perimbangan 2:1 bagi laki-laki dan perempuan, itu merupakan perimbangan bagian yang tidak adil. Terutama dihubungkan dengan perkembangan zaman sekarang yang sekurang-kurangnya dalam banyak kasus, dunia kerja dan/atau dunia usaha dalam konteks pendapatan ekonomi dan keuangan rumah tangga, tidak lagi menjadi monopoli kaum laki-laki seperti halnya di masa-masa lalu. Di zaman modern kini, dunia kerja/usaha, juga sudah menjadi domain kaum

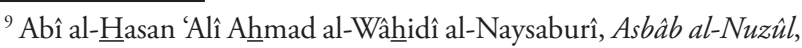
(Bayrût, Lubnân: Dâr al-Fikr, t.th.), h. 99-100. 
perempuan dalam hal ini istri atau ibu dalam sebuah rumah tangga. Bahkan dalam kasus-kasus tertentu, tidak jarang penghasilan ekonomi keuangan istri/ ibu, jauh lebih besar daripada penghasilan ekonomi keuangan para suami/ayah.

Pertanyaannya, di manakah letak makna dan filosofi keadilan hukum kewarisan Islam yang tetap mengusung perimbangan pembagian harta waris dengan 2:1 itu? Apakah pembagian ini tidak berarti bias gender dan mendiskreditkan kaum perempuan dengan lebih berpihak kepada kaum laki-laki? Sayangnya, kaum pro penyamaan atau perimbangan pembagian kewarisan ini hanya mengandalkan logika nisbi, di samping hanya merujuk kepada kasus-kasus tertentu yang jumlahnya belum atau tidak sebanding dengan kenyataan di lapangan bahwa sampai sekarang ini, secara umum dan keseluruhan, dunia kerja/usaha bagaimanapun masih tetap didominasi oleh kaum laki-laki. Benar dalam kasus-kasus tertentu terutama di kota-kota besar, atau bahkan di beberapa daerah perkampungan sekalipun, telah banyak kaum perempuan yang memiliki keterampilan lebih dibandingkan kaum laki-laki dalam hal pencarian nafkah rumah tangga seperti halnya yang dialami oleh para tenaga kerja wanita (TKW), namun keadaan demikian masih tetap belum bisa memastikan bahwa jumlah kaum pekerja/pengusaha perempuan jauh lebih besar daripada kaum laki-laki.

Selintas, "tawaran" pemikiran untuk mengubah perimbangan kewarisan dari 2:1 menjadi 1:1 ini memang terkesan filosofis dan terlihat lebih adil daripada perimbangan 2:1, misalnya, terutama ketika terma "adil" diartikan dengan makna sama persis atau persis sama: sama banyak dan atau sama besar. Namun, pengubahan perimbangan pembagian kewarisan dari 2:1 menjadi $1: 1$, hemat penulis, tidaklah sesederhana itu dan tidak serta-merta memastikan keadilan dalam kehidupan rumah tangga. Sebab, masih banyak hal lain yang mutlak perlu dipertimbangkan dan dipikirkan masak-masak, sebelum sampai pada keputusan untuk mengubah perimbangan 2:1 menjadi 1:1, apalagi dengan pengubahan yang sebaliknya yakni 1:2. Baik dari segi dalil akli (kontekstualis), dan lebih-lebih dari sisi dalil naqlî (tekstualis), tentu dengan samasama menggunakan argumentasi yang bersifat ilmiahakademik.

Usulan pengubahan perimbangan pembagian kewarisan Islam dari 2:1 menjadi 1:1 untuk ahli waris laki-laki dan perempuan, apalagi untuk dilakukan secara umum dan menyeluruh, selain terkesan terlampau simplistik dan terburu-buru-untuk tidak mengatakan mengada-ada apalagi mengada-adakanjuga alasannya kurang argumentatif dalam arti tidak memiliki basis pemikiran hukum Islam yang kuat baik dari sisi normatif-tekstualis, dan lebih-lebih dari sudut padang dalil yang substantif-kontekstualis, apalagi argumentasi yang bersifat filosofis-psikologis, dan dari sudut pandang kesiapan dan ketulusan seorang mukminmuminah untuk menerima hukum-hukum Allah secara tulus ikhlas tanpa reserve. Sebaliknya, pemikir-pemikir yang mempertahankan pembagian kewarisan dengan perimbangan 2:1 juga sangat mungkin terkesan atau dikesankan tekstualis.

Penolakan terhadap usulan pengubahan perimbangan pembagian hukum kewarisan Islam ini didasarkan pada beberapa alasan. Pertama, memaknai kata adil atau keadilan dengan sama banyak atau benarbenar sama, adalah sama sekali tidaklah benar, apalagi tepat. Sebab, kata adil atau keadilan (al-'adllal-'adâlah) memiliki banyak makna. Di samping berarti sama banyak, adil juga berarti seimbang, sebanding, sepadan, dan lain-lain. Pendeknya, adil tidak harus selalu dan selamanya identik benar dengan sama banyak. Keadilan lebih dititikberatkan pada pengertian "meletakkan sesuatu pada tempatnya (proporsional)". Berlaku adil terkait dengan hak dan kewajiban; hak dan kewajiban terkait pula dengan amanah; sementara amanah wajib diberikan kepada orang (dalam hal ini ahli waris) yang berhak menerimanya. ${ }^{10}$

Kedua, para "penolak" hukum kewarisan Islam memandang kewarisan sebagai sistem hukum yang berdiri sendiri, tidak ada kaitan dengan sub sistemsub sistem hukum keluarga lainnya. Padahal, hukum kewarisan dalam Islam sesungguhnya hanya merupakan sub sistem yang bersama-sama sub sistem-sub sistem lainnya merupakan bagian tidak terpisahkan dari sistem hukum keluarga Islam secara keseluruhan. Karenanya, maka hukum waris tidaklah mungkin berdiri sendiri dalam arti tidak mungkin bisa terlepas apalagi sengaja dipisahkan dari sistem hukum keluarga dalam konteksnya yang bersifat umum, padu, dan menyeluruh. Hukum kewarisan Islam tidak hanya mematok ihwal pembagian dan perimbangan distributif antara hak waris anak laki-laki dan anak perempuan, antara hak waris suami dan istri, antara hak waris ayah dan ibu, apalagi cuma sekadar hak waris laki-laki anak tertua atau hak waris anak perempuan saja, sebagaimana dikenal dalam sistem hukum Adat, terutama adat patrilinial murni yang dianut hukum kewarisan Adat jahiliah maupun hukum kewarisan adat zaman modern sekarang ini.

Sekali lagi harus ditegaskan bahwa hukum waris Islam hanya merupakan sub sistem dari keseluruhan sistem hukum keluarga Islam. Terutama terkait dengan sub sistem hukum perkawinan dan sub sistem hukum

${ }^{10}$ Tim Penyusun, Ensiklopedi Hukum Islam, (Jakarta: Ikhtiar BaruVan Hoeve, 1997), Jilid II, h. 25. 
keturunan (nasab) yang menjadi asas bagi keberadaan (eksistensi) hukum kewarisan Islam itu sendiri. Belum lagi dikaitkan dengan ihwal mahar (mas kawin) dan hukum nafkah keluarga yang selalu menjadi kewajiban suami.

Ketiga, kaum penolak hukum kewarisan Islam boleh jadi memandang akal pikiran mampu memecahkan semua masalah, termasuk persoalan pelik yang mengandung rahasia yang tidak terjangkau oleh akal pikiran sebagaimana terkandung di balik ketidaksamaan pembagian hak kewarisan dalam sistem kewarisan itu, yang menyebabkan penalarannya sangat dipengaruhi oleh kondisi yang bersifat kasuistis-sosiologis. Padahal, sistem hukum kewarisan Islam diatur langsung oleh Allah-melalui Alquran-dengan pengaturan dan penetapan hukum yang bersifat jelas, tegas, lugas, dan bahkan secara umum dapat dikatakan tuntas. Kenyataan ini, antara lain, ditandai dengan penetapan ahli waris, bagian masing-masing ahli waris, waktu pembagian warisan, berikut mekanisme pengaturannya. Ini menunjukkan bahwa Allah Swt.-yang secara hukum memiliki hak prerogatif, ${ }^{11}$ telah menetapkan hukum kewarisan Islam berdasarkan ayat-ayat mubkamât yang lebih banyak dari jumlah ayat-ayat hukum yang mengatur distribusi zakat sekalipun.

Keempat, ada beberapa dalil lain yang perlu direnungkan bersama, manakala perimbangan waris 2:1 itu hendak diubah menjadi 1:1. Beberapa alasan dimaksud ada yang bersifat tekstualis maupun kontekstualis. Bagian ayat-ayat yang tekstualis dan kontekstualis, di antaranya adalah sebagai berikut:

Pertama, kalimat مفروضانصيبا (bagian yang telah ditentukan), yang menjadi penutup ayat 7 surah alNisâ’ [4]. Menurut al-Zamakhsyarî, dinasabkan atas pertimbangan khusus dengan maksud bahwa Allah memberikan bagian yang telah ditentukan secara pasti dan mesti (maqthîa wâjiba: definitif), yang tidak boleh tidak dan mesti demikian adanya. ${ }^{12}$

Kedua, kalimat في اولادكم الله يوصيكم (Allah mewasiatkan kepada kamu tentang hal [pembagian harta kewarisan]). Wasiat, yang secara literal artinya pesan. Al-Thabrasî, salah seorang tokoh ulama Syiah Imamiyah abad VI Hijriyah, ketika menafsirkan penggalan ayat ini menyatakan abhwa Allah memerintahkan dan memfardukan atas kamu wasiat, mengingat wasiat dari Allah itu adalah perintah dan keharusan (amr wa fardh) yang menunjukkan itu. ${ }^{13}$ Paling tidak sebagian ulama, meng-istinbâth-kan hukum dari penggalan

\footnotetext{
${ }_{11}$ Perhatikan Alquran, antara lain surah al-Mầidah [5]: 1.

${ }^{12}$ Abî al-Qâsim Jar Allâh Mahmûd ibn 'Umar al-Zamakhsyarî alKhawarizmî, al-Kasysyâf 'an Haqẩiq al-Tanzîl wa-'Uyûn al-Aqwil fî̀ Wujûh al-Tảwîl, (Bayrut, Lubnân: Dâr al-Fikr, t.th.), Jilid I, h. 503.

${ }^{13}$ Abû 'Alî al-Fadhl ibn al-Hasan al-Thabrasî, Majmá al-Bayân fî̀
}

ayat ini bahwasanya Allah lebih kasih sayang daripada orang tuanya sekalipun kepada anaknya sendiri tatkala Allah mewasiati kedua orang tua terkait dengan hakhak warisan anak-anaknya. Hal ini diperkuat dengan ungkapan yang menyatakan الله أرحم من هذَه بولدها (Allah itu lebih sayang terhadap hamba-Nya tentang urusan itu [dibandingkan] dengan anaknya sekalipun). ${ }^{14}$

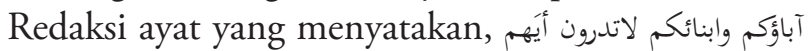
(bapak-bapak kamu dan/atau anak-anak kamu tidak tahu persis tentang [rahasia pembagian waris yang demikian itu], mana di antara mereka itu sesungguhnya yang lebih dekat/besar manfaatnya), apakah bapaknya atau anaknya? apakah yang perempuan atau yang lakilaki? Ketika menafsirkan penggalan ayat ini, al-Thabrasî mengemukakan beberapa kemungkinan penafsirannya. Pertama, seperti dikatakan Mujâhid, maknanya ialah bahwa "kalian (ahli-ahli waris) tidak akan pernah tahu mana lebih bermanfaat bagi kalian di dunia ini sehingga kalian memberikan hak kewarisan itu kepada ahli-ahli waris dengan sesuka kamu. Tetapi Allah telah menentukan bagian masing-masing itu sedemikian rupa menurut yang Dia ketahui mengenai hikmah apa yang akan terjadi di balik penetapan pembagian itu."

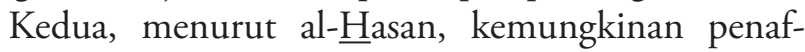
sirannya adalah bahwa "kalian tidak akan pernah tahu di mana letak kebahagiaan kamu dalam urusan dunia maupun agama. Sementara Allah mengetahui tentang itu dan karenanya maka Dia-lah yang berhak membagikan (menentukan bagiannya) sesuai dengan yang Dia jelaskan dan sesuai pula dengan kemaslahatan”.

Ketiga, bisa juga maknanya ialah bahwa "kalian (manusia) itu tidak tahu bahwa kemanfaatan itu justru terlahir dengan sebab pendidikan yang kalian terima dari bapak-bapak kalian itu lebih besar, atau manfaat bapakbapak kamu disebabkan khidmat (pengabdiannya) terhadap kalian, terutama terkait dengan pemberian belanja yang kalian terima dari ayah-ayah kalian di saat-saat mereka memasuki usia tua", demikian kata alJubbầ $\hat{1}^{15}$

فريضة من الله (itu semua ketentuan dari Allah), yakni "kalian tidak mengetahui yang sesungguhnya mengapa Allah menentukan pembagian waris oleh diri-Nya sendiri, dan Dia-lah pula yang menentukan (kepastian) bagian-bagain kewarisan itu menurut apa yang Dia ketahui tentang hikmahnya, sehingga kemudian ditemukan kemaslahatan dan kemanfaatan (yang ada di dalamnya), tanpa disadari oleh manusia yang oleh Allah

\footnotetext{
Tafsîr al-Qur'ân, (Bayrût, Lubnan: Dâr al-Fikr, t.t.), Juz III, h. 23-24.

14 Muhammad 'Alî al-Shâbûnî, Shafwah al-Tafâsîr, Bayrût, Lu nân: Dâr al-Fikr, [t.t.]., Jilid I, h. 265.

${ }^{15}$ Abû 'Alî al-Fadhl ibn al-Hasan al-Thabrasî, Majma' al-Bayân fî̀ Tafsîr al-Qur'àn, Majma' al-Bayân fì Tafsîr al-Qur'ân, (Bayrût, Lubnân: Dâr al-Fikr, t.th.), h. 22.
} 
diberi juga akal pikiran dan (sedikit) ilmu pengetahuan. Jika urusan pembagian kewarisan itu diserahkan sepenuhnya kepada manusia (seperti yang dikehendaki oleh sebagian orang sekarang ini) yang belum tentu atau bahkan tidak mengerti perihal kemanfaatannya bagi mereka sendiri, maka boleh jadi mereka (manusia) itu akan meletakkan harta kekayaan, dalam hal ini harta waris, di luar hikmah yang sesungguhnya. ${ }^{16}$

Itulah pula sebabnya mengapa Allah menyertai

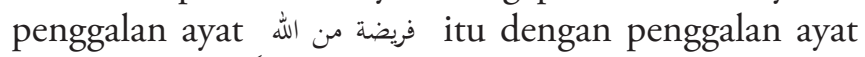
(sesungguhnya Allah itu adalah Yang Mahatahu lagi Mahabijaksana). Allah itu Mahatahu tentang apa yang paling maslahat untuk makhluk-Nya. Lagi pula Dia lebih bijaksana dengan apa (hukum) yang Dia syariatkan dan Dia fardukan, termasuk hukum faraid. Terkait dengan penggalan ayat ini, masih ada beberapa ayat senada lainnya yang mengisyaratkan hak prerogatif Allah dalam hal penetapan hukum. Di antaranya adalah ayat, انَ الله يكمم مايريد (sesungguhnya Allah itu menetapkan hukum [dalam konteks ini hukum waris] menurut hukum-hukum yang Dia kehendaki). ${ }^{17}$

Masih terkait dengan penafsiran tekstual ayat-ayat mawârits, renungkan pula penggalan-penggalan ayat lainnya, terutama غير مضار (yang tidak membahayakan).

([pembagian waris] itu adalah wasiat (pesan) dari Allah), bukan pesan apalagi pesananan manusia termasuk nabi dan/atau rasul sekalipun. Pertanyaannya, mengapa manusia lebih peduli dan menghormati wasiat manusia dibandingkan dengan mematuhi wasiat Allah tentang hukum kewarisannya itu?

(dan Allah itu Maha Mengetahui lagi Mahabijaksana). Pengulangan redaksi inna Allâh kâna 'alìma-n hakîma-n dan wa Allâh 'alîmu-n hakî̀m, ini mengisyaratkan bahwa ketentuan ilmu faraid adalah ketentuan yang benar-benar sudah pasti. Makanya, tidaklah mengherankan jika sebagian pakar faraid menempatkan ijbârî (imperatif) sebagai salah satu asas hukum faraid. Dan seterusnya, di antara hal sangat menarik terkait dengan pembagian tuntas kewarisan Alquran adalah kalimat yang menyatakan bahwa pembagian waris itu adalah wasiat dari Allah (washiyyah min Allâh). Penyebutan kata wasiat dalam dua ayat warisan ini saja (al-Nisầ (4): 11-12) tidak cuma satu kali dan dalam satu bentuk, akan tetapi sebanyak sepuluh kali dan dalam beberapa bentuk. Pertanyaannya, tepatkah wasiat Allah [perimbangan 2:1] itu kita langgar atau khianati menjadi 1:1? Bagaimana mungkin? Wasiat manusia saja tidak boleh dilanggar, kecuali kalau berlawanan dengan aturan hukum Allah/ nabi-Nya yang ada. ${ }^{18}$ Apa hikmah yang terkandung

\footnotetext{
${ }^{16}$ Muhammad 'Alî al-Shâbûnî, Shafwah al-Tafâsîr, Jilid I, h. 263.

${ }^{17}$ Perhatikan Alquran surah al-Mầidah [5]: 1.

${ }^{18}$ Perhatikan Alquran, terutama surah al-Ahzâb [33]: 36.
}

dalam penyebutan kata wasiat yang bersifat istimrâr (pengulangan berkali-kali) ini?

Dari sejumlah penggalan ayat-ayat di atas, dapat dipahami dan disimpulkan bahwa jika urusan pembagian harta peninggalan (tirkah) mayit itu tidak akan menimbulkan dampak negatif apapun sekiranya diserahkan kepada manusia, terutama para ahli warisnya, maka pembagiannya tentu Allah akan serahkan saja kepada manusia (dalam hal ini ahli waris). Tetapi, karena Allah Mahatahu lagi Mahabijaksana sampai masalah-masalah yang sekecil apapun yang dipastikan tidak terdeteksi oleh otak manusia secermat dan seencer apapun, maka tidaklah mengherankan manakala Allah Swt. menggunakan hak prerogatif-Nya dalam urusan pembagian kewarisan itu, apatah lagi dengan melibatkan ahli-ahli waris yang sangat mungkin lebih mementingkan dirinya sendiri tanpa melirik hak-hak orang lain yang ada di sekitarnya. ${ }^{19}$

Kelima, hampir atau bahkan semua pakar tafsir $a \underline{h} k \hat{a} m$ setuju untuk menyatakan bahwa ayat-ayat mawârîts tergolong ke dalam deretan ayat-ayat mubkamât yang oleh Alquran sendiri diposisikan sebagai umm alkitâb (induk Alquran). Sebaliknya, tidak ada mufassir ayat a $\underline{h} k \hat{a} m$ yang memosisikan ayat-ayat waris sebagai ayat-ayat mutasyâbihâat. Sejalan dengan pemikiran para mufassir ayat a $\underline{b} k \hat{a} m$, ahli-ahli usul fikih (al-ushûliyyûn) juga pada umumnya atau bahkan semuanya menyetujui untuk mengatakan bahwa ayat-ayat mawârîts tergolong ke dalam kategori ayat-ayat qathiyyât, baik dari segi dilâlah-nya maupun dari segi wurûd-nya. ${ }^{20}$

Keenam, Ayat-ayat dan Hadis-hadis mawârîts, pada dasarnya dan dalam kenyataannya bersifat tafshîlî dan muqayyad. Tidak ada yang bersifat ijmâlî, apalagi bersifat mutlak. Kebalikannya, pengubah perimbangan bagian kewarisan dari 2:1 menjadi 1:1, me-mujmal-kan yang tafshîl dan me-muthlaq-kan yang muqayyad. 'Allal al-Fashî, pengarang kitab aI-Maqâshid al-Syarî'ah alIslâmiyyah wa Makârimih â, menggolongkan dasar-dasar ikatan hukum keluarga dan hukum waris ke dalam komponen ayat-ayat hukum yang legislasinya bersifat rinci (al-tasyrî̀ al-tafshîlî̀), dalam arti perinciannya sudah ditetapkan dalam kitab Allah (Alquran) sedemikian rupa yang menyebabkan kaum mujtahidin tidak lagi mendapatkan tempat untuk memberikan pemahaman tambahan dan peng-istinbâth-an cabang-cabang hukumnya. ${ }^{21}$

Ketujuh, pengubahan perimbangan pembagian

\footnotetext{
${ }^{19}$ Muhammad 'Alî al-Shâbûnî, Shafwah al-Tafâsîr, Jilid I, h. 263.

${ }^{20}$ Lihat beberapa kitab usul fikih yang menunjuk kepada ayat-ayat kewarisan (âyât al-mawârîtsi) tatkala mereka mencontohkan ayat-ayat yang qathiyyât.

21 'Allal al-Fasî, Maqâshid al-Syarîah al-Islâmiyyah wa Makârimihâ, (Bayrût, Lubnân: Dâr al-Qalam), h. 88.
} 
waris juga tampak tidak sesuai dengan ayat-ayat wa'd (janji baik) dan waî̀ (ancaman buruk), terutama ayat 13 dan 14 surah al-Nisầ [4], yang secara tekstual posisinya menyertai ayat-ayat kewarisan, sementara secara kontekstual menekankan manusia supaya menghormati dalam arti mematuhi hukum-hukum Allah dan tegas-tegas melarang pengingkarannya. Ayatayat $w a^{\prime} d$ dan $w a^{\prime} i d$ yang dimaksudkan adalah ayat-ayat pendukung ayat-ayat waris maupun ayat-ayat terkait, terutama surah al-Nisầ [4]: 65 dan al-Ahzzâb [33]: 36, di samping surah al-Nisâ’ [4]: 13 dan 14.

Kedelapan, paling tidak sebagian ahli tafsir a $\underline{k} k \hat{a} m$, ada pula yang berkomentar bahwa ayat induk kewarisan ini memiliki posisi yang sangat sentral dan strategis dalam mengawal keberlangsungan penerapan dan pengamalan sistem hukum waris dengan posisi yang sangat penting. Al-Syawkânî (w. $1250 \mathrm{H}$ ) dan al-Qurthubî, misalnya, keduanya menyatakan bahwa ayat 11-12 surah al-Nisầ [4], ini adalah sebagai rukun dari rukun-rukun agama, sebagai tiang dari tiang-tiang hukum, dan sebagai induk dari induk-induk ayat ( $h a \hat{d} d z i h$ al-âyah rukn min arkân al-dîn, wa umdah min ümad al-abhkâm, wa umm min ummahât al-ayât). Alasannya, mengingat faraid sangat agung kadar nilainya, sampaisampai ilmu faraid porsinya disebut-sebut sepertiga ilmu (tsuluts al-ïlm), atau bahkan setengah/separuh ilmu (nishf al-ilm) sebagaimana telah dibahas lebih dulu. Sayangnya, ilmu faraid ini juga disebut-sebut sebagai bidang ilmu yang tergolong ke dalam deretan ilmu yang [segera] akan dilupakan (diabaikan) orang, ${ }^{22}$ karena isi kandungannya yang memuat hal-hal yang sangat penting dari ilmu faraid, yakni ilmu yang sangat mulia kedudukannya di mata para sahabat, terutama kaum analisnya dari mereka. ${ }^{23}$

Kesembilan, senafas dengan pe-mubkamât-an dan peng-qath'iyyât-an ayat-ayat induk mawârîts yang diperkuat oleh ayat-ayat pendukung maupun ayatayat terkait, maka dengan sedirinya tidak ada lagi celah untuk mencoba memaksakan pengubahan ayatayat mawârîts menjadi ayat-ayat mutasyâbihât dengan cara memaksakan penakwilan yang menggunakan alasan-alasan sumir-baik karena sifatnya yang locally maupun mengingat peristiwanya yang kasuistissehingga menyebabkan siapa saja bisa terseret ke area mutasyabihât yang menimbulkan sifat zaygh di dalam hatinya sebagaimana diingatkan Alquran, dalam hal ini surah Âli ‘Imrân [3]: 7.

${ }^{22}$ Muhammad ibn 'Alî ibn Muhammad al-Syawkânî, Fath al-Qâdir al-Jâmi' bayn Fannai al-Riwâyah wa al-Dirâyah, (Bayrût, Lubnân: Dâr al-Fikr, t.th.), juz I, h. 431.

${ }^{23}$ Abû 'Abd Allâh Muhammad ibn Aḥmad al-Anshârî al-Qurthubî, al-Jâmi' li A $\underline{h k a ̂ m}$ al-Qur'ân, Bayrût, Lubnân: Dâr al-Fikr, t.th.), h. 5556.

\section{Hikmah Pelipatan Bagian Laki-laki}

Ulama klasik maupun kontemporer sesungguhnya telah lama berusaha mencoba dan bahkan bekerja keras untuk mencari tahu dan memberikan jawaban tentang rahasia apa di balik kebijakan Allah Swt. melipatgandakan bagian kewarisan kaum laki-laki, terutama anak dan suami, daripada anak perempuan dan istri, antara lain:

Pertama, Muhammad 'Ali al-Shâbûnî, salah seorang pakar tafsir a $\underline{h a k m}$ kontemporer, menyatakan bahwa di antara hikmah dari pelipatan bagian laki-laki yang sama dengan bagian dua orang anak perempuan atau bagian seorang suami yang dua kali lipat lebih besar daripada bagian istri, ialah mengingat kebutuhan suami/ayah untuk membiayai (menafkahi) kehidupan rumah tangganya, di samping pengelolaan aset perniagaan, usaha ekonomi, dan pertanggungjawaban berat lainnya, jauh lebih besar dibandingkan dengan yang dibutuhkan istri/anak perempuan, sehingga dia (laki-laki) benar-benar memerlukan pembiayaan kehidupan yang lebih banyak/besar seiring dengan beberapa kewajiban (tanggung-jawabnya) yang lebih berat dibandingkan dengan tanggung jawab orangorang perempuan yang karenanya maka laki-laki itu sangat lebih membutuhkan harta-kekayaan daripada perempaun. ${ }^{24}$ Itulah pula sebabnya mengapa dalam kasus tertentu tatkala mayit hanya meninggalkan ahli waris yang terdiri atas: ayah, ibu, dan beberapa saudara, maka bagian ibu hanya $1 / 6$, sedangkan bapak/ayah adalah sisanya (ashâbah), itu juga di antara hikmahnya ialah karena suami dan ayah, secara hukum memang dibebani tanggungan nafkah (biaya) kehidupan rumahtangga yang secara hukum sama sekali tidak dibebankan apalagi diwajibkan kepada pihak istri/ibu. ${ }^{25}$

Kedua, Ahmad Musthafâ al-Marâghî dalam karyanya, Tafsir al-Marâghî, menyatakan bahwa di antara hikmah Allah menjadikan bagian laki-laki itu sama dengan bagian dua orang anak perempuan, itu didasarkan atas pertimbangan bahwa laki-laki itu selain membutuhkan pembiayaan untuk kehidupan dirinya sendiri, juga memikul tanggungjawab pembiayaan untuk menghidupi istri dan anak-anaknya yang menyebabkan Allah Swt. memberikan dua saham bagi suami dan satu saham untuk istri. Sedangkan istri, dengan pembiayaan hidup dari suaminya, tidak memerlukan biaya hidup dari apalagi oleh dirinya sendiri, di samping sama sekali tidak ada kewajiban untuk membiayai diri sendiri dan/atau untuk membiayai anak/anak-anaknya,

\footnotetext{
${ }^{24}$ Muhammad 'Alî al-Shâbûnî, Shafwah al-Tafâsîr, Jilid I, h. 265.

${ }^{25}$ Muhammad 'Alî al-Shâbûnî, Shafwah al-Tafâsîr, Jilid I, h. 263; Rafiq Yûnus al-Mashrî, Fiqh Mu'âmalah al-Mâliyyah, (Damsyiq: Dâr al-Qalam, 1429 H/2009 M), h. 71.
} 
apalagi untuk membiayai kehidupan suaminya. Lagi pula, kalau istri yang ditinggal mati oleh "si mayit" menikah lagi dengan laki-laki lain, maka ia akan mendapatkan hak pembiayaan hidup (hak nafkah) dari suaminya yang baru. Padahal, bila yang menikah lagi itu suaminya, maka suami diharuskan membiayai kehidupan istri barunya itu di samping membiayai kehidupannya sendiri. ${ }^{26}$ Demikian pula kalau si suami melakukan poligini, dia dibebani tanggung jawab untuk memberikan nafkah kepada semua istri-istrinya.

Ketiga, al-Jakani al-Syanqithî (Muhammad al-Amîn ibn Muhammad al-Mukhtâr), pengarang tafsir Adhwâ al-Bayân Tafsìr al-Qur'ân bi al-Qur'ân, berkomentar bahwa Allah Swt. memang tidak memberikan penjelasan tesurat terkait tentang hikmah apa yang ada di balik perahasiaan perimbangan bagian 2:1 untuk ahli waris laki-laki dan ahli waris perempuan itu, padahal keduanya (ahli waris laki-laki dan hali waris perempuan) memiliki kedudukan yang sama dalam artian sejajar/sederajat dalam hal kekerabatannya. Namun demikian, kata alSyanqithî, Allah mengisyaratkan alasan/hikmah dari perimbangan pembagian warisan yang berbeda itu pada ayat yang lain, yakni surah al-Nisâ' (4): 34 yang sudah dikutipkan di atas. Ayat ini, menurut al-Syanqithî, memosisikan kaum pria (suami/ayah) sebagai al-qẩim 'ala ghayrih (penegak dan pelindung untuk orang lain dalam hal ini keluarga) di atas kaum perempuan (istri/ ibu) yang diposisikan sebagai al-maqûm 'alayh (المقوم عليه) dalam arti yang dilindungi yaitu pihak yang berhak menerima pengayoman dan perlindungan (al-munfaq 'alayh).

Dengan demikian, sesuai dengan fungsi dan perannya sebagai al-qẩim 'alâ ghayrih, laki-laki adalah penanggung jawab pembiayaan kehidupan rumah tangga yang karenanya maka harta laki-laki akan selalu keluar dan mengurang, dan bahkan habis. Sementara harta perempuan yang sejatinya diposisikan sebagai penerima nafkah (al-maqûm 'alayh), dengan sendirinya maka hartanya akan selalu bertambah atau minimal tidak berkurang karena tidak ada kewajiban pengeluaran untuk keperluan pembelanjaan apapun. ${ }^{27}$ Tapi jangan kaitkan dengan inflasi yang tidak ada sangkut-pautnya dengan ihwal kewarisan.

\section{Kemungkinan Pengubahan 2:1 Menjadi 1:1}

Bila perimbangan pembagian hukum kewarisan Islam 2:1 itu hendak diubah menjadi 1:1 atau apalagi dengan perimbangan berbeda lainnya, maka menurut hemat

${ }^{26}$ Ahmad Mushthafâ al-Marâghî, Tafsî̀ al-Marâghî, (BayrûtLubnân: Dâr al-Fikr, t.th.), Jilid II, h. 196.

27 Muhammad al-Amîn ibn Muhammad al-Mukhtar al-Jakanî al-Syanqithî, Adhwa' al-Bayân Tafsìr al-Qur'ân bi al-Qur'ân, (Bayrût, Lubnân: Dâr al-Fikr, t.th.), h. 308. penulis, kemungkinannya hanya melalui tiga alternatif. Pertama, pengubahan perimbangan bagian hukum kewarisan yang notabene hanya merupakan sub sistem dari hukum keluarga, itu harus didahului atau minimal dibarengi dengan pengubahan sub sistem hukum keluarga yang lainnya, dalam hal ini hukum perkawinan terutama yang terkait dengan pembebanan kewajiban yang serba sepihak yaitu pembayaran mahar (maskawin) dan terutama kewajiban membiayai kehidupan keluarga yang secara hukum hanya dibebankan kepada suami/ bapak, tidak kepada istri/ibu. Bahwa dalam praktik ada kasus urusan kehidupan rumah-tangga yang secara ekonomi dan keuangan ditulangpunggungi oleh pihak istri/ibu, itu merupakan soal lain yang lahir dan terjadi semata-mata lebih disebabkan panggilan moral dalam artian iktikad baiknya, bukan atas dasar apalagi paksaan hukum Islam sebagaimana adanya.

Kedua, pembagian waris tetap dilakukan dengan perimbangan 2:1. Setelah itu barulah anak/saudara laki-laki memberikan sebagian harta miliknya itu kepada saudara atau saudara-saudara perempuannya. Cara demikian boleh jadi dirasakan berbelit-belit secara teknis, tetapi bagaimana pun cara inilah yang lebih sesuai dengan prinsip pembagian hukum kewarisan itu sendiri. Cara ini juga lebih sejalan dengan pendirian sebagian ahli fikih yang memandang pembagian waris lebih berdimensikan hak daripada diposisikan sebagai kewajiban. Tetapi pada saat yang bersamaan, juga tidak menyalahi prinsip orang yang berpendirian bahwa pembagian waris merupakan norma hukum yang wajib ditaati apa adanya oleh insan-insan Muslim dan Muslimah.

Ketiga, ini sesungguhnya bukan alternatif yang dibenarkan dari sisi paham keislaman. Tetapi tidaklah salah dari sudut pandang kemerdekaan seseorang untuk beriman atau tidak beriman, yaitu bila tetap memaksakan kehendak untuk mengubah perimbangan hukum waris Islam dari 2:1 menjadi 1:1. Tidak perlu, atau bahkan tidak lagi berhak mengatasnamakan hukum waris Islam, karena secara konteks apalagi teks, tidak ada hukum Islam yang menerapkan pembagian kewarisan Islam dengan sama banyak atau sama sedikit.

Bahwa dalam praktik ada tokoh-tokoh atau masyarakat Muslim tertentu yang menerapkan asas pembagian 1:1, maka itu dapat dipastikan atas dasar ijtihad atau tepatnya kehendak dirinya sendiri yang boleh jadi tampak salah dan menyalahi lahiriah tekstual maupun kontekstual, bahkan substansi nas itu sendiri, bukan atas dasar konteks apalagi teks wahyu yang lazim diidentikkan dengan hukum Islam itu sendiri. Dari sisi mana pun, ide pembagian kewarisan dengan prinsip perimbangan 1:1 tidak memiliki landasan tekstual (dalil naqlî), baik dari Hadis dan lebih-lebih 
dari Alquran. Padahal, yang namanya hukum Islam itu adalah khithâb Allâh.

\section{Penutup}

Dari pembahasan ini, penulis lebih cenderung menyimpulkan bahwa baik secara umum dan keseluruhan, maupun secara rinci dan kasus demi kasus sekalipun, hukum kewarisan Islam itu dari sisinya yang manapun, secara teoretik tampak sangat jelas, lengkap, dan adil. Termasuk dengan perimbangan pembagiannya yang menggunakan pendekatan 2:1 untuk ahli waris laki-laki dan ahli waris perempuan. Karenanya, hukum kewarisan Islam sama sekali tidak bias gender, apalagi diskriminatif.

Kunci untuk memahami dan menerimanya, harus menempatkan posisi kewarisan sebagai sub sistem dari sistem hukum keluarga secara keseluruhan bahkan harus dipahami sebagai bagian integral dari keseluruhan sistem hukum Islam yang bersifat utuh dan menyeluruh. Atas dasar ini maka perimbangan 2:1 dalam kewarisan Islam, tetap proporsional, prosedural, dan proporsional, mulai dari segi pemerataan dan keadilan sampai persoalan sosiologi dan psikologi hukum.

Atas dasar ini maka kemungkinan mengubah perimbangan pembagian warisan dari 2:1 menjadi $1: 1$, secara umum dan keseluruhan, tidak dapat dipertanggungjawabkan secara hukum. Alasannya, mengingat secara umum dan keseluruhan, semua ayat mawârits terutama ayat-ayat induknya, tergolong ke dalam ayat-ayat mubkamât-qathiizyyât, baik dari segi dilâlah-nya dan lebih-lebih dari sisi wurûd-nya. Sebagai ayat muhkamât dan qathiyyât, menurut teorinya tidak boleh diubah apalagi dipaksa-paksa mengubah untuk menerima penakwilan sedemikian rupa. Pengubahan ayat mawârîts dari ayat mubkamât-qathiyyât ke dalam ayat zhanniyyât, apalagi mutasyâbihâât, pelakunya bisa jadi termasuk ke dalam deretan orang-orang yang oleh Alquran disebut zaygh.

Satu-satunya jalan untuk mengubah hukum kewarisan Islam (faraid) sebagai sub sistem dari hukum keluarga (al-a hawâl al-syakhshiyyah), adalah harus dibarengi dengan pengubahan sub sistem hukum keluarga yang lainnya, dalam hal ini hukum perkawinan dan hukum kerumahtanggaan. Permasalahannya kini, siapkah kita mengubah secara total sistem hukum keluarga Islam yang telah berjalan dan dijalankan secara turun-temurun mulai zaman nabi Muhammad Saw. sampai sekarang di se antero jagat raya ini? []

\section{Pustaka Acuan}

Al-Qur'ân al-Karîm

AlMunawwir, Ahmad Warson, Al-Munawwir Kamus
Arab-Indonesia, Yogyakarta: Pondok Pesantren alMunawwir, 1984.

Departemen Pendidikan Nasional, Kamus Besar Bahasa Indonesia, Jakarta: Balai Pustaka, 2005.

Doi, 'Abd Rahman I., Shariah: The Islamic Law, Kualalumpur-Malaysia: Zafar Sdn. Bhd., 2002.

Fasî, al-, 'Allal, Maqâshid al-Syarîah al-Islâmiyyah wa Makârimihâ, Bayrût, Lubnân: Dâr al-Qalam, 1993.

Ghundur, al-, 'Abd al-'Azhîm Ma'ânî dan Aḥmad, A $\underline{h a ̂ m}$ min al-Qur'ân wa al-Sunnah, Mashr: Dâr alMa’ârif, 1387 H/1967 H.

Marâghî, Ahmad Mushthafâ, Tafsîr al-Marâghî, BayrûtLubnân: Dâr al-Fikr, t.th.

Mashrî, al-, Rafiq Yûnus, Fiqh Mu'âmalah al-Mâliyyah, Damsyiq: Dâr al-Qalam, 1429 H/2009 M.

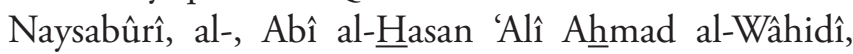
Asbâb al-Nuzûl, Bayrût, Lubnân: Dâr al-Fikr, t.th.

Qurthubî, al-, Abû 'Abd Allâh Muhammad ibn Ahmad al-Anshârî, al-jâmi' li A $\underline{b} k \hat{a} m$ al-Qur'ân, Bayrût, Lubnân: Dâr al-Fikr, t.th.

Shabûnî, al-, Muhammad 'Alî, Rawâii al-Bayân Tafsîr Ayât al-A $\underline{h} k \hat{a} m$, Bayrût, Lubnân: Dâr al-Fikr, t.th.

--------, Muhammad 'Alî, Shafwah al-Tafâsîr, Bayrût, Lubnân: Dâr al-Fikr, [t.t.].

Suma, Muhammad Amin, Himpunan Undang-Undang Pedata Islam dan Peraturan Pelaksanaan Lainnya di Negara Hukum Indonesia, Jakarta: Raja Wali Press, 2008.

Syaltût, Mahmûd, Al-Islâm 'Aqîdah wa Syarîah, Bayrût, Lubnân: Dâr al-Qalam, 1967.

Syanqithî, al-, Muhammad al-Amîn ibn Muhammad al-Mukhtar al-Jakanî, Adhwa' al-Bayân Tafsîr al-Qur'ân bi al-Qur'ân, Bayrût, Lubnân: Dâr al-Fikr, t.th.

Syathî, Muhammad al-Shâdiq, Lubab al-Farẩidh Syâmil

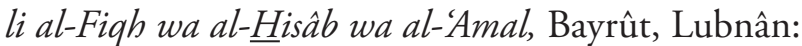
Dâr al-Gharb al-Islâmî, 1408 H/1988 M.

Syawkânî, al-, Muhammad ibn 'Alî ibn Muhamammad, Fath al-Qâdir al-Jâmi' bayn Fannai al-Riwâyah wa al-Dirâyah, Bayrût, Lubnân: Dâr al-Fikr, t.th.

Thabrasî, al-, Abû 'Ali al-Fadhl ibn al-Hasan, Majma' al-Bayân fî̀ Tafsî̀ al-Qur'ân, Bayrût, Lubnân: Dâr alFikr, t.th.

Tim Penyusun, Ensiklopedi Hukum Islam, Jakarta: Ikhtiar Baru-Van Hoeve, 1997.

Zamakhsyari, al-, al-Khawarizmî, Abî al-Qâsim Jâr Allâh Mahmûd ibn 'Umar, al-Kasysyâf' 'an Haqẩiq al-Tanzîl wa 'Uyûn al-Aqâwîl fi Wujûh al-Ta'wîl, Bayrut, Lubnân: Dâr al-Fikr, t.th. 